\title{
Ethnobotanical perspective of antimalarial plants: traditional knowledge based study
}

\author{
Abdul Qayum ${ }^{1,3^{*}}$, Rakesh Arya² and Andrew M. Lynn
}

\begin{abstract}
Background: Considering the demand of antimalarial plants it has become essential to find and locate them for their optimal extraction. The work aims to find plants with antimalarial activities which were used by the local people; to raise the value of traditional knowledge system (TKS) prevalent in the study region; to compile characteristics of local plants used in malaria treatment (referred as antimalarial plants) and to have its spatial distribution analysis to establish a concept of geographical health.
\end{abstract}

Methods: Antimalarial plants are listed based on literature survey and field data collected during rainy season, from 85 respondents comprised of different ethnic groups. Ethno-medicinal utilities of plants was extracted; botanical name, family, local name, part used, folklore, geographical location and image of plants were recorded after cross validating with existing literatures. The interview was trifurcated in field, Vaidya/Hakims and house to house. Graphical analysis was done for major plants families, plant part used, response of people and patients and folklore. Mathematical analysis was done for interviewee's response, methods of plant identification and people's preferences of TKS through three plant indices.

Results: Fifty-one plants belonging to 27 families were reported with its geographical attributes. It is found plant root $(31.75 \%)$ is used mostly for malaria treatment and administration mode is decoction (41.2\%) mainly. The study area has dominance of plants of family Fabaceae (7), Asteraceae (4), Acanthaceae (4) and Amaranthaceae (4). Most popular plants found are Adhatoda vasica, Cassia fistula and Swertia chirata while \% usage of TKS is $82.0 \%$ for malaria cure.

Conclusion: The research findings can be used by both scientific community and common rural people for biodiscovery of these natural resources sustainably. The former can extract the tables to obtain a suitable plant towards finding a suitable lead molecule in a drug discovery project; while the latter can meet their local demands of malaria, scientifically.

Keywords: Antimalarial plants, Ethnobotany, Ethnoecology, Geographical health, Medicinal plants, Plant indices, Traditional knowledge system

\section{Background}

Traditional medicine plays a pivotal role in the economy and sustainable growth of developing nations especially for poor countries like India. The preventive health measures have still not been able to penetrate the

\footnotetext{
*Correspondence: qayum.iitk@gmail.com

${ }^{1}$ Center for Biology and Bioinformatics, School of Computational and Integrative Sciences, Jawaharlal Nehru University, New Delhi 110067 India

Full list of author information is available at the end of the article
}

economically downtrodden societies including typical rural and schedule tribe areas. Their life is purely dependent on traditional knowledge system (TKS) of herbal plants for medicinal cure purposes. The native people are exploiting a variety of herbals for effective curing of various ailments and most widely malaria. Such herbal plants possess potential remedy even for some incurable diseases as well. The plant parts used, preparation method of medicine from it, and its administration as drug varies geographically [1]. However, the knowledge of herbal 
medicines is gradually perishing, although some of the traditional herbal men like Vaidyas and Hakims are still practicing the art of herbal healing effectively in such regions. Ethno-medicinal and ethno-botanical studies have offered immense scope and opportunities for the development and synthesis of new drugs. Modern drugs have been deducted from folklore and traditional medicines [2].

Malaria is a culprit that has victimized almost half of the modern civilization and it is endemic across more than 100 countries [3]. Malaria is a major public health problem in India, 40 million people are suffering from this single celled Plasmodium, a protozoan parasite and more than 1.5 million confirmed cases are reported annually by the National Vector Borne Disease Control Programme (NVBDCP), New Delhi of which 40-50\% is due to Plasmodium falciparum (Pf). However, in the study area malaria is only due to Plasmodium vivax as Pf count was found to be zero [4]. Malaria can be considered as poor man's disease and hence it requires focussed planning both at the level of government and at the community level.

In the Tarai regions of Eastern Uttar Pradesh (UP) the spreading of vector borne diseases becomes uncontrolled especially during rainy seasons [4]. In recent studies, chloroquine-resistant $P$. falciparum malaria has been observed with increasing incidence in the whole country, while it was effective for treating nearly all cases of malaria in the past. P. falciparum has become drug resistant now. The continued treatment of such cases with chloroquine is probably one of the factors responsible for the increased proportion of $P$. falciparum cases relative to $P$. vivax [5]. The current malaria therapies include methods such as passive surveillance of malaria, use of artemisinin combination therapy (ACT) and introduction of intervention like rapid diagnostic tests (RDT) for malaria cure [6]. The commercial industry on antimalarial drug is facing huge a challenge primarily due to development of drug resistance of malarial parasites. And, hence biodiscovery of antimalarial plants has become inevitable towards discovering a novel plant in order to find a lead compound towards malaria medication efforts. It is very likely that in times to come sustainable harvesting of this natural wealth needs to be done to meet the public health demands.

In this circumstance, ethnobotanical and ethnoecological study of antimalarial plants in three districts of Eastern UP was carried out. The native communities have been using their unique traditional knowledge (TK) system, culture, indigenous skills and expertise since the ancient times towards the disease control. TK refers to the ancient and non-conventional practices towards disease control mechanism. Local knowledge of a community is spread across various diseases and masses from developing countries utterly rely on the herbal treatment methods. India has witnessed its legacy from the times of Charaka and Susruta for traditional knowledge for antimalarial activities of various medicinal plants [7]. Considering the high time demand of antimalarial plant it has become inevitable to find and locate them for its optimal extraction for antimalarial actions.

A series of similar work has been done by many people in the country including Verma et al. [2] that has found 72 plant species in campus of Banares Hindu University, Varanasi, UP and has compiled the traditional uses by the local inhabitants. Ethnobotanical work has also been done for the Gorakhpur regions [8,9] while Kumar and Akhtar [10] have worked on ethanomedicinal solanaceous plants of eastern UP and have found 14 species of medicinal angiosperms. Qayum et al. [1] has done geographic information system based study for antimalarial plants in three districts of UP to highlight geographical attributes of these plants. Tomar [11] has worked on folk medicinal uses of plant roots of Meerut city and has found 39 medicinal plant species belonging to 39 genera and 28 families which are used by rural and common people for various diseases. Srivastava [12] has done ethnobotanical exploration with respect to food values of 27 underutilized edible fruits consumed by ethnic people of north-eastern terai region of UP and have established database of these fruits which is useful in bio-discovery projects for achieving food security and environmental sustainability. Shankar et al. [13] have listed all the antimalarial plants of north east India and has emphasized the need for an alternative drug for malaria for developing new antimalarial plants from the indigenous plants.

Panda et al. [14] have documented phyto-therapeutical practices in Mayurbhanj district of Orissa, eastern India and has described 112 plants from 62 families which are therapeutically used against different ailments including malaria. Bahekar and Kale [15] on "Herbal Plants Used for the Treatment of Malaria" have highlighted many plants which are used since ancient times for the treatment of malaria and have established pharmacotherapy is the most common treatment strategy for the disease. Sampath et al. [16] have described Swertia chirata as a traditional herb and has found it is used as a preventative measure for malaria during epidemics. Kamaraj et al. [17] has done an ethno-pharmacological investigation on antimalarial activities of medicinal plants traditionally used in the villages of Dharmapuri regions of south India and has identified 24 such plants.

The research objectives are to find all possible plants in the study area with antimalarial activities which were used by the local people and the tribes. This was intended to know and appreciate the TK system based medication 
prevalent in the region. Therefore, it is aimed to compile and list characteristics of antimalarial plants prevalent in three districts of Kushinagar, Maharajganj and Gorakhpur of eastern UP and to show the distribution of antimalarial in various geographical regions. Further, the scope of present work has been extended to find out geographical health $(\mathrm{GH})$ of antimalarial plants. $\mathrm{GH}$ refers to the state of plant presence in the study area. It is found that many plants are at the verge of either extinction, critically endangered or vulnerable [18]. Hence, immediate attention is highly expected from policy makers to safeguard the interest of people at large and some immediate action is needed from the government bodies to safeguard the current bio-diversity and medicinal plant richness of the region.

The current work is a fine mixture of literature survey and supplemented with collected information through interviews and field visits after cross validating the study area findings from Vaidyas/Hakims, and native rural people. The TK skills and practices thus developed are freely exchanged, cared for and nourished as a common property of the communities [19]. The current work has also highlighted the geographical location of antimalarial plants along with listing them with its family name, folklore, and image of plant in its natural habitat and geographical health has also been explored. It is anticipated that with these observations; traditional method of malaria cure can be accelerated especially for the low socio-economic regions where modern health measures are nearly absent.

\section{Methods}

\section{Study area}

The study area lies in the north-eastern corner of the most populous state of UP, India. It comprises a large stretch lying to the north of the river Rapti tributary to the Gandak river and also surrounded by Rohini river at northern side which is the major source of water in the region. The area comprised of three district of UP viz. Gorakhpur, Kushinagar and Maharajganj (Fig. 1). It has total area of $9291 \mathrm{Km}^{2}$ (3.82\% of the state). This much of land area is home to people of countries like, Greece, Portugal, Sweden, etc. It also shares international borders with Nepal. The study area is one among highly dense region of the country (average density around 1210 people per $\mathrm{Km}^{2}$ ) and is home to more than 10.67 million Indian population [20]. The region is one among several vector borne diseases sensitive zones especially for Japanese encephalitis and malaria.

The study region is home to Tharu, Buksa, Raji and Jaunsari tribes $(114,876$ people) which are $1.075 \%$ of total population. Two religious communities Hindus
(82\%) and Muslims (15\%) find dominance while Buddhists and others constitute $3 \%$ population of the study area. The economics is primarily based on agriculture (97.48 \%) with 87,400 main industry working and to some extent on tourism because of presence of Kushinagar Baudh temple (one of the main attraction for the Buddhists). As per the recent census (2011) of UP, India [20] total Population of study area is $10,690,142$ (Table 1) with $48.60 \%$ female population and $1,680,587$ as total house hold of which $87.98 \%$ is rural house hold. The rural people migrate to big cities for work very often. Entire study area happens to be least developed part of one of the poorest State in India. It makes low socio-economic profile for the region with $3,462,855$ total work participation (female: $28.3 \%$ ) and 1,708,932 main work participation (female: $19.1 \%$ ) and 1,753,923 marginal worker (female: $37.3 \%$ ) (Fig. 1).

\section{Methodology}

The work has been carried out as per the schematic flowchart (Fig. 2) and its various dimensions are

\section{Pre-ethnobotanical surveys}

Before conducting actual ethnobotanical survey pre-ethnobotanical survey was conducted to set the standard goal targets. It began with extraction of ethno-medicinal utilities of plants extracted from the relevant literature available in journals and books and cross examined with accessing traditional knowledge (TK) available with local community including tribal. Numerous related publications of different journals, accepted literature from books like Flora of upper Gangetic Plains [21], Flora Gorakhpurensis [22], Herbal Medicines [23] were searched and cross examined with databases like PubMed Central (PMC) and finally this collected information was compared with the field data collected.

\section{Ethnobotanical survey setup}

Survey was conducted in the study area based on the interviews of respondents chosen on criteria discussed below. The interview was trifurcated with respect to field, Vaidya/Hakims and house to house (Table 2). Total of 51 plants (Table 3) were recorded and tabulated. Interview was conducted to find out number of positive cases (n) towards malaria treatment for a particular plant of the region.

\section{Sampling method}

The survey was conducted during rainy (July-October 2013) months (Malaria epidemic season). Local population based survey sampling relying on TK system was 


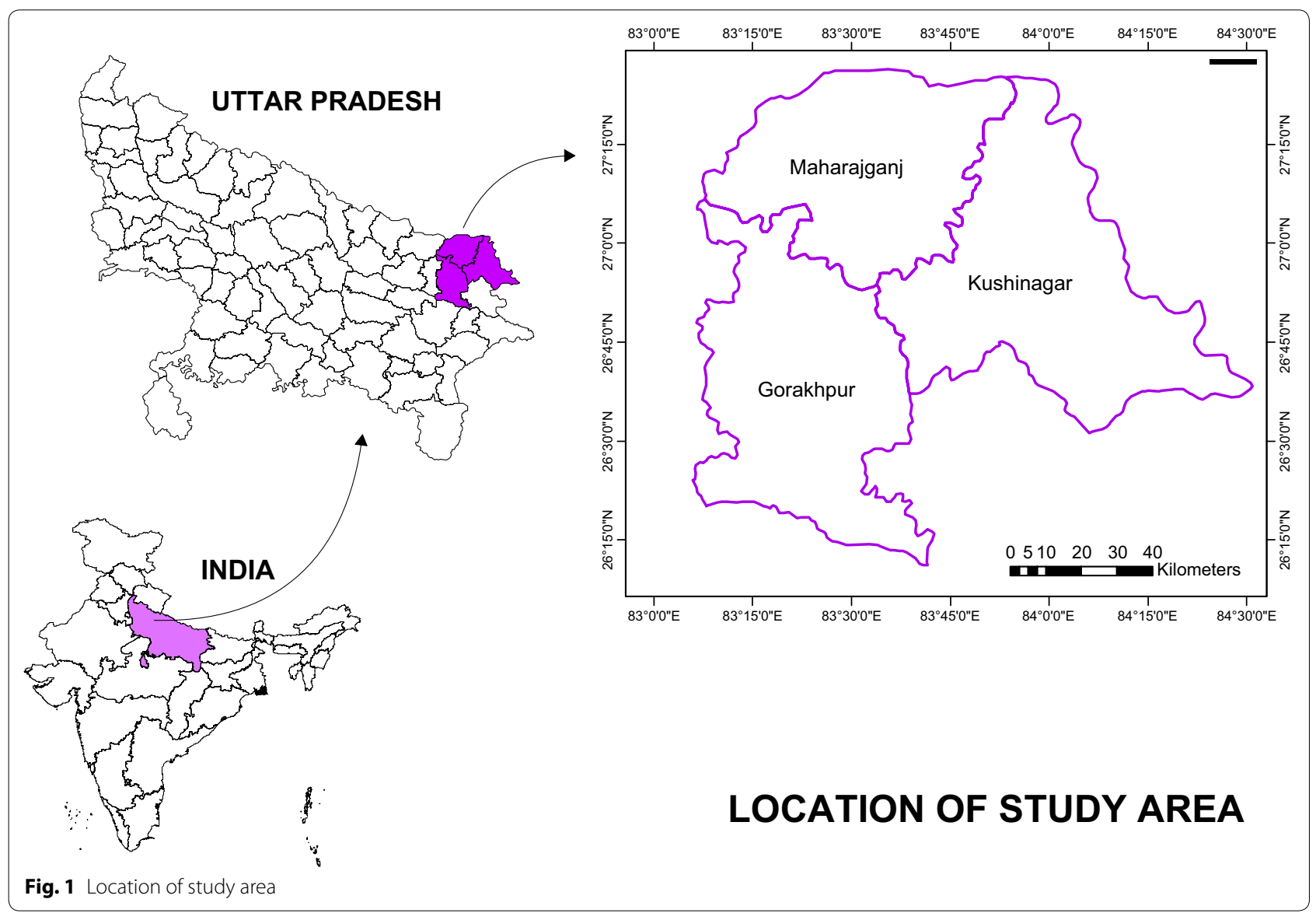

Table 1 Socio-economic profile of the study area

\begin{tabular}{llcrrr}
\hline District name & Population type & Total house hold & Total population & Total male & Total female \\
\hline Gorakhpur & Rural & 554,999 & $3,604,766$ & $1,838,726$ & $1,766,040$ \\
& Urban & 137,961 & 836,129 & 439,051 & 397,078 \\
& Total & 692,960 & $4,440,895$ & $2,277,777$ & $2,163,118$ \\
Kushinagar & Rural & 533,834 & $3,396,437$ & $1,730,377$ & $1,666,060$ \\
& Urban & 27,228 & 168,107 & 87,678 & 80,429 \\
& Total & 561,062 & $3,564,544$ & $1,818,055$ & $1,746,489$ \\
Maharajganj & Rural & 175,359 & $1,101,460$ & 564,281 & 23,349 \\
& Urban & 7497 & 45,201 & 537,179 \\
& Total & 182,856 & $1,146,661$ & 587,630 & 559,031 \\
\hline
\end{tabular}

Source: census of India, 2011

followed. Survey locality chosen based on the study of API (Annual parasitic index) of Malaria obtained from District Malaria Office. All those areas with relatively high API were selected for the survey while respondents were chosen based on their interface with TK System and this information was obtained from a local survey while herbalists (Vaidya/Hakim) of the locality were given precedence. In total 85 independent respondents were chosen from Gorakhpur (22), Kushinagar (38) and Maharajganj (35) districts (Table 4).

\section{Identification of plants}

Ethnobotanical data collected was observed by expert taxonomist and botanist Dr. H.B. Naithani (Senior Scientist, FRI University Dehradun, India) and taxonomic details were ascertained (Table 3). Botanical names of 


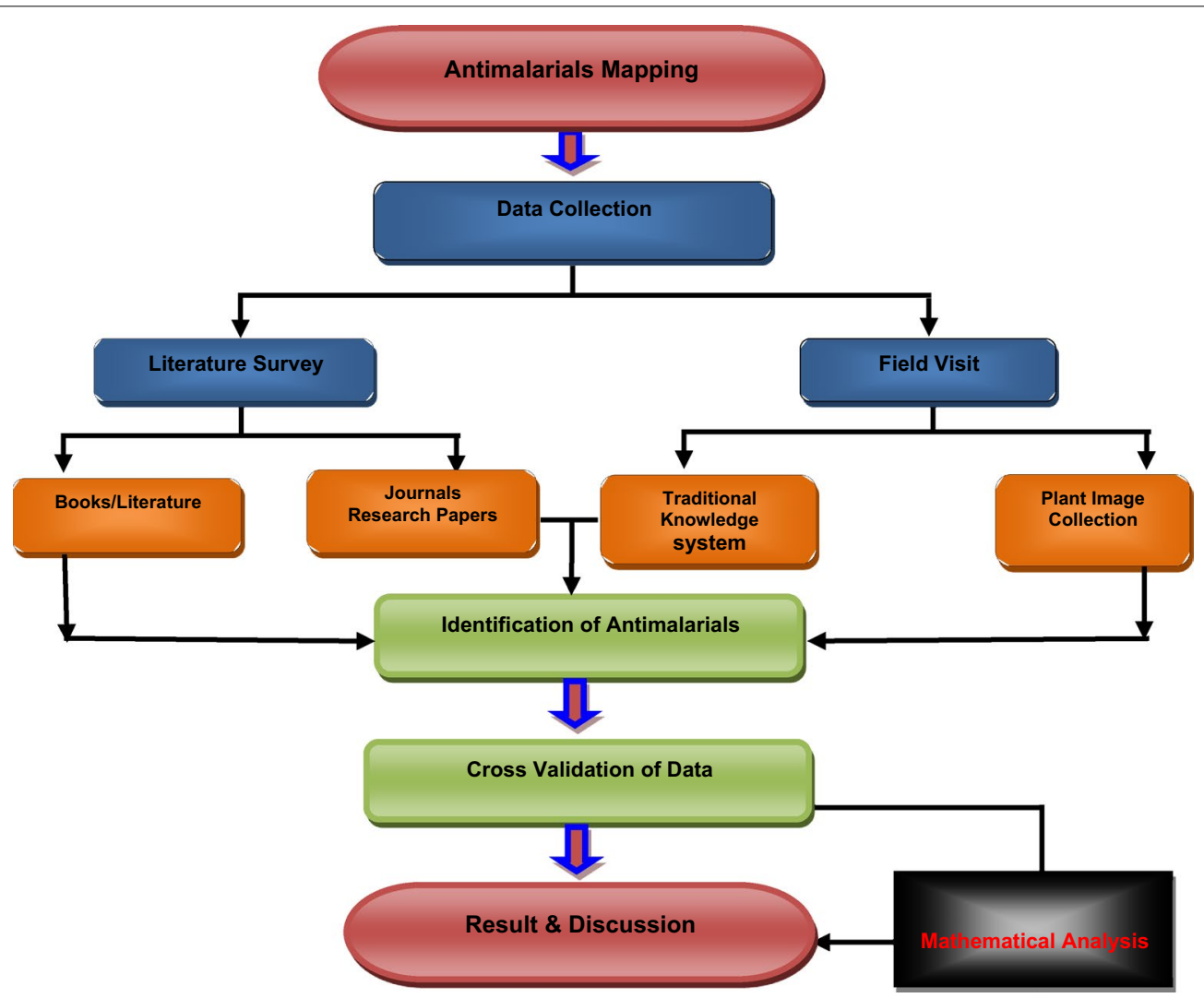

Fig. 2 Schematic flowchart for the identification of antimalarial plants

plants and authority were established and cross. The data obtained from ecological sampling was used to determine geographical health of any plant in terms of vulnerable, nearly extinct or under threat. This was specified in terms of PK (percentage known) $=0$ or PI (plant impression) as 'unknown'.

\section{Ethics statement and consent}

This is to declare that the work has no completing interest. All respondents actively participated and the survey was purely participative and voluntarily in nature. Participants provided verbal informed consent to participate in this study. They were free to withdraw their information at any point of time. Participant consent was recorded on the designed sheet. The authors adhered with ISE 2006 and 2008 guidelines and all the principles laid down were followed. The entire voucher numbers of specimen collected were deposited in Forest Research Institute, Dehradun herbarium (Voucher Number 10787-10837). The work did not involve any protected area (National Park, Wildlife Sanctuary or Private Plantation). It was done on the land which can be easily accessed by the public and hence no such permission was required. The field studies did not involve any endangered or protected species.
GPS co-ordinates for the study region are: Gorakhpur (Lat. $26^{\circ} 13^{\prime} \mathrm{N}$ to $27^{\circ} 29^{\prime} \mathrm{N}$ and Long. $83^{\circ} 05^{\prime} \mathrm{E}$ to $83^{\circ} 56^{\prime} \mathrm{E}$ ), Kushinagar (Lat. $26^{\circ} 39^{\prime} \mathrm{N}$ to $27^{\circ} 15^{\prime} \mathrm{N}$ and Long. $83^{\circ} 38^{\prime} \mathrm{E}$ to $84^{\circ} 15^{\prime} \mathrm{E}$ ) and Maharajganj (Lat. $26^{\circ} 59^{\prime} \mathrm{N}$ to $27^{\circ} 19^{\prime} \mathrm{N}$ and Long. $83^{\circ} 09^{\prime} \mathrm{E}$ to $83^{\circ} 45^{\prime} \mathrm{E}$ ).

\section{Interview details and criteria}

Eighty-five respondents from all ethnic groups comprising Tharu tribes, Hindus, Muslims were interviewed against designed format of set of questions like collection date, local name, plant image, plant location/region, plant description, method of usage of plant in malarial cases. There were 63 male and 22 female respondents from all three major localities (Table 4). No pre-test was conducted as the obtained information was cross validated with the existing TK system in literature databases (PMC etc.). Elderly (as they are TK rich) people above 50 years (mean age 52.0 years) and mainly males $(74.12 \%)$ were interviewed because of their easy availability. Samples were collected throughout the study area making each geographical representation possible (such as people residing in the area of forest, near water bodies, urban areas and rural areas). Participants were chosen based on their experience and as well as age. Plant 
Table 2 Methods of plant identification and people's preferences

\begin{tabular}{|c|c|c|c|c|c|c|c|c|}
\hline \multirow[t]{2}{*}{ Plant species } & \multirow[t]{2}{*}{ Families } & \multicolumn{3}{|c|}{ Method of interview } & \multirow{2}{*}{$\begin{array}{l}\text { Positive } \\
\text { response }(n)\end{array}$} & \multirow[t]{2}{*}{ PK (\%) } & \multirow[t]{2}{*}{ PR } & \multirow[t]{2}{*}{$\mathrm{Pl}^{\mathrm{a}}$} \\
\hline & & Field $(\sqrt{ })$ & $\begin{array}{l}\text { Vaidya/ } \\
\text { hakim }(*)\end{array}$ & $\begin{array}{l}\text { House } \\
\text { to house (\#) }\end{array}$ & & & & \\
\hline Abrus precatorius Linn. & Fabaceae & & & \# & 26 & 30.6 & 3 & Fair \\
\hline Acacia farnesiana (L.) Willd. & Fabaceae & $\sqrt{ }$ & & & 0 & 0 & 3 & Unknown \\
\hline Achyranthes aspera Linn. & Amaranthaceae & $\sqrt{ }$ & * & & 30 & 35.1 & 1 & Fair \\
\hline Adhatoda vasica Nees & Acanthaceae & $\sqrt{ }$ & * & $\#$ & 49 & 57.3 & 1 & Good \\
\hline Aerva lanata (L.) Juss. ex Schult. & Amaranthaceae & $\sqrt{ }$ & & \# & 6 & 7.1 & 2 & Poor \\
\hline Alstonia scholaris (L.) R.Br. & Apocyanaceae & & * & & 29 & 34.1 & 1 & Fair \\
\hline $\begin{array}{l}\text { Alternanthera sessilis (L.) R.Br. } \\
\text { exDC. }\end{array}$ & Amaranthaceae & & & $\#$ & 6 & 7.1 & 2 & Poor \\
\hline Amaranthus spinosus Linn. & Amaranthaceae & $\sqrt{ }$ & & & 4 & 4.7 & 3 & Poor \\
\hline Ammannia baccifera Linn. & Lythraceae & $\sqrt{ }$ & & & 0 & 0 & 3 & Unknown \\
\hline $\begin{array}{l}\text { Andrographis paniculata Wall. ex } \\
\text { Nees }\end{array}$ & Acanthaceae & $\sqrt{ }$ & * & $\#$ & 46 & 53.8 & 1 & Good \\
\hline Asteracantha longifolia (L.) Nees & Acanthaceae & & & $\#$ & 8 & 9.4 & 3 & Poor \\
\hline Azardirachta indica A.Juss & Meliaceae & $\sqrt{ }$ & & $\#$ & 27 & 31.8 & 1 & Fair \\
\hline Barleria prionitis Linn. & Acanthaceae & & & $\#$ & 12 & 14.1 & 2 & Poor \\
\hline Bauhinia variegata Linn. & Fabaceae & $\sqrt{ }$ & * & $\#$ & 43 & 50.3 & 1 & Good \\
\hline Boerhaavia diffusa L.nom.cons. & Nyctaginaceae & & * & & 26 & 30.6 & 1 & Fair \\
\hline Caesalpinia crista (Linn.) & Fabaceae & & * & & 28 & 32.9 & 2 & Fair \\
\hline Carica papaya Linn. & Caricaceae & $\sqrt{ }$ & * & $\#$ & 45 & 52.7 & 1 & Good \\
\hline Cassia fistula Linn. & Fabaceae & $\sqrt{ }$ & * & $\#$ & 51 & 59.7 & 1 & Good \\
\hline Cissampelos pareira Linn. & Menispermaceae & $\sqrt{ }$ & & & 0 & 0 & 3 & Unknown \\
\hline Citrus medica Linn. & Rutaceae & & & $\#$ & 11 & 12.9 & 2 & Poor \\
\hline Clerodendron infortunatum Linn. & Verbenaceae & $\sqrt{ }$ & & $\#$ & 9 & 10.6 & 2 & Poor \\
\hline Cosmos sulphureus Cav. & Asteraceae & $\sqrt{ }$ & & & 0 & 0 & 3 & Unknown \\
\hline Cuscuta reflexa Roxb. & Convolvulaceae & & * & & 32 & 37.6 & 1 & Fair \\
\hline Cyperus scariosus Br. & Cyperaceae & & * & & 28 & 32.9 & 2 & Fair \\
\hline Datura metel Linn. & Solanaceae & $\sqrt{ }$ & & & 11 & 12.9 & 2 & Poor \\
\hline Eclipta prostrata (Linn.)Linn & Asteraceae & $\sqrt{ }$ & & $\#$ & 17 & 20.0 & 1 & Poor \\
\hline Erythrina variegata Linn. & Fabaceae & $\sqrt{ }$ & & & 0 & 0 & 3 & Unknown \\
\hline Jatropha gossypifolia Linn. & Euphorbiaceae & $\sqrt{ }$ & & & 0 & 0 & 3 & Unknown \\
\hline Lantana camara Linn & Verbenaceae & $\sqrt{ }$ & & $\#$ & 13 & 15.3 & 1 & Poor \\
\hline Leucas aspera (Willd.) Link. & Lamiaceae & & & $\#$ & 26 & 30.6 & 2 & Fair \\
\hline $\begin{array}{l}\text { Ludwigia octovalvis (Jacq.) P.H. } \\
\text { Raven }\end{array}$ & Onagraceae & & & $\#$ & 7 & 8.2 & 3 & Poor \\
\hline Magnolia grandiflora Linn. & Magnoliaceae & $\sqrt{ }$ & & & 0 & 0 & 3 & Unknown \\
\hline Momordica charantia Linn. & Cucurbitaceae & & & $\#$ & 3 & 3.5 & 3 & Poor \\
\hline Murraya koenigii (L.) Sprengel & Rutaceae & $\sqrt{ }$ & & & 8 & 9.4 & 2 & Poor \\
\hline Nyctanthes arbor-tristis Linn. & Oleaceae & & * & & 10 & 11.8 & 1 & Poor \\
\hline Ocimum sanctum Linn. & Lamiaceae & & & $\#$ & 28 & 32.9 & 1 & Fair \\
\hline Oenanthe javanica (BL.) DC. & Apiaceae & $\sqrt{ }$ & & $\#$ & 13 & 15.3 & 2 & Poor \\
\hline Piper longum Linn. & Piperaceae & & * & $\#$ & 30 & 35.1 & 1 & Fair \\
\hline Pongamia pinnata (L.) Pierre & Fabaceae & & * & $\#$ & 45 & 52.7 & 1 & Good \\
\hline Putranjiva roxburghii (Wall.) & Euphorbiaceae & $\sqrt{ }$ & & $\#$ & 27 & 31.8 & 2 & Fair \\
\hline $\begin{array}{l}\text { Rauvolfia serpentine (Linn.) } \\
\text { Benth. }\end{array}$ & Apocynaceae & $\sqrt{ }$ & & & 4 & 4.7 & 3 & Poor \\
\hline Scoparia dulcis Linn. & Scrophulariaceae & $\sqrt{ }$ & & & 0 & 0 & 2 & Unknown \\
\hline Sida rhombifolia Linn. & Malvaceae & $\sqrt{ }$ & & $\#$ & 5 & 5.9 & 2 & Poor \\
\hline Solanum indicum Linn. & Solanaceae & $\sqrt{ }$ & * & & 12 & 14.1 & 1 & Poor \\
\hline
\end{tabular}


Table 2 continued

\begin{tabular}{|c|c|c|c|c|c|c|c|c|}
\hline \multirow[t]{2}{*}{ Plant species } & \multirow[t]{2}{*}{ Families } & \multicolumn{3}{|c|}{ Method of interview } & \multirow{2}{*}{$\begin{array}{l}\text { Positive } \\
\text { response (n) }\end{array}$} & \multirow[t]{2}{*}{ PK (\%) } & \multirow[t]{2}{*}{ PR } & \multirow[t]{2}{*}{$\mathrm{PI}^{\mathrm{a}}$} \\
\hline & & Field $(\sqrt{ })$ & $\begin{array}{l}\text { Vaidya/ } \\
\text { hakim }\left({ }^{*}\right)\end{array}$ & $\begin{array}{l}\text { House } \\
\text { to house (\#) }\end{array}$ & & & & \\
\hline $\begin{array}{l}\text { Stephania japonica (Thunb.) } \\
\text { Miers }\end{array}$ & Menispermaceae & $\sqrt{ }$ & & & 3 & 3.5 & 3 & Poor \\
\hline Streblus asper Lour. & Moraceae & $\sqrt{ }$ & & & 0 & 0 & 3 & Unknown \\
\hline Swertia chirata Buch.Ham & Gentianaceae & $\sqrt{ }$ & * & \# & 48 & 56.2 & 1 & Good \\
\hline $\begin{array}{l}\text { Tinospora cordifolia (Thunb.) } \\
\text { Miers. }\end{array}$ & Menispermaceae & $\sqrt{ }$ & * & \# & 43 & 50.3 & 1 & Good \\
\hline Vandellia sessiliflora Benth. & Scrophulariaceae & $\sqrt{ }$ & & & 0 & 0 & 3 & Unknown \\
\hline Vernonia cinerea (Linn.) Less. & Asteraceae & $\sqrt{ }$ & & \# & 0 & 0 & 3 & Unknown \\
\hline Xanthium strumarium Linn. & Asteraceae & $\sqrt{ }$ & * & & 20 & 23.5 & 2 & Poor \\
\hline
\end{tabular}

a $\mathrm{PI}$ is 'Good' if PK $\geq 50 \%$, 'Fair' if $30 \% \leq \mathrm{PK}<50 \%$, 'Poor' if $0<\mathrm{PK}<30 \%$, and 'Unknown' if PK $=0 \%$

images have been taken from the plant's natural habitat to build digital database to facilitate the easy recognition of plant by the local people and later it is integrated with the known traditional applications of these plants as antimalarial plants. The interview was done in three modes of field, Vaidya/Hakims and house to house to strengthen the data collection process and at the finally it was cross checked.

\section{Data collection}

Data on ethno-medicinal applications of plants are collected in the sequences of: Serial number, botanical name, family, vernacular/local name, part used, methodology used, plant location, and plant image. Later, collected data was referenced using surveyed literature and databases. Demographic and socio-economic survey was also done to find correlation with malaria epidemic with these factors. Additional information (Additional file 1) like age of respondents, education background, monthly income and occupation was also recorded (Table 4). It was also queried for how frequent people use TK system for malaria cure.

\section{Data analysis}

Data obtained through ethnobotanical survey was analyses through following parameters:

1. Percentage known (PK): This is \% of people who have knowledge of usage of plant species for malaria treatment and calculated as: $\mathrm{PK}=[\mathrm{n} / \mathrm{m}] \times 100 ; \mathrm{n}=$ total number of positive responses and $\mathrm{m}=$ total number of respondents.

2. Preference ranking (PR): It is similar to the rank system used by Asase et al. [24]. Here, plants were ranked as per their effectiveness towards treatment. Rank 1, 2 and 3 were assigned where rank 1 means highly effective in treatment while rank 3 means least effective.
3. Plant impression (PI): It is the index indicating how a plant is perceived in the locality. PI is comprised of four categories as good, fair, poor and unknown. PI is 'Good' if PK $\geq 50$ \%; 'Fair' if $30 \leq \mathrm{PK}<50 \%$; 'Poor' if $0<\mathrm{PK}<30 \%$; and 'Unknown' if PK $=0 \%$. PK $=0$ means plant is unknown among community people but found in the field and also available in the literatures.

4. Graphical analysis: Pie charts have been drawn to assess the most frequent part of plant usage in TK system of antimalarial plants (Graph 1), major plant families (Graph 2), response of people and patients (Graph 3) and folklore (Graph 4).

5. Analysis of the interviewee response [17] has been presented (Tables 2 and 4) to include observations related to geographical profile of study area, literacy, monthly income, occupation etc.

\section{Results}

Traditional knowledge system of antimalarial plants: Compilation of all antimalarial plants prevalent in the region (Table 3).

Graphical analysis (Fig. 3): Four pie charts are drawn and results are:

- Roots are mainly (31.8 \%) used towards malaria cure (Graph1).

- As many as 12 plant families have more than one plant in the region (Graph 2) and Fabaceae family makes highest influence of 7 plants in the list (Table 3).

- Response of people and patients was analysed. It was found that $41.2 \%$ responses are 'poor' while $19.6 \%$ people are unknown for any TK Based system in the region (Graph 3).

- In $41.2 \%$ cases plant part used as decoction followed by plant usage as juices or in some form of beverage\# $(27.5 \%)$ and plants are also used as mosquito repellent (2\%) (Graph 4). 


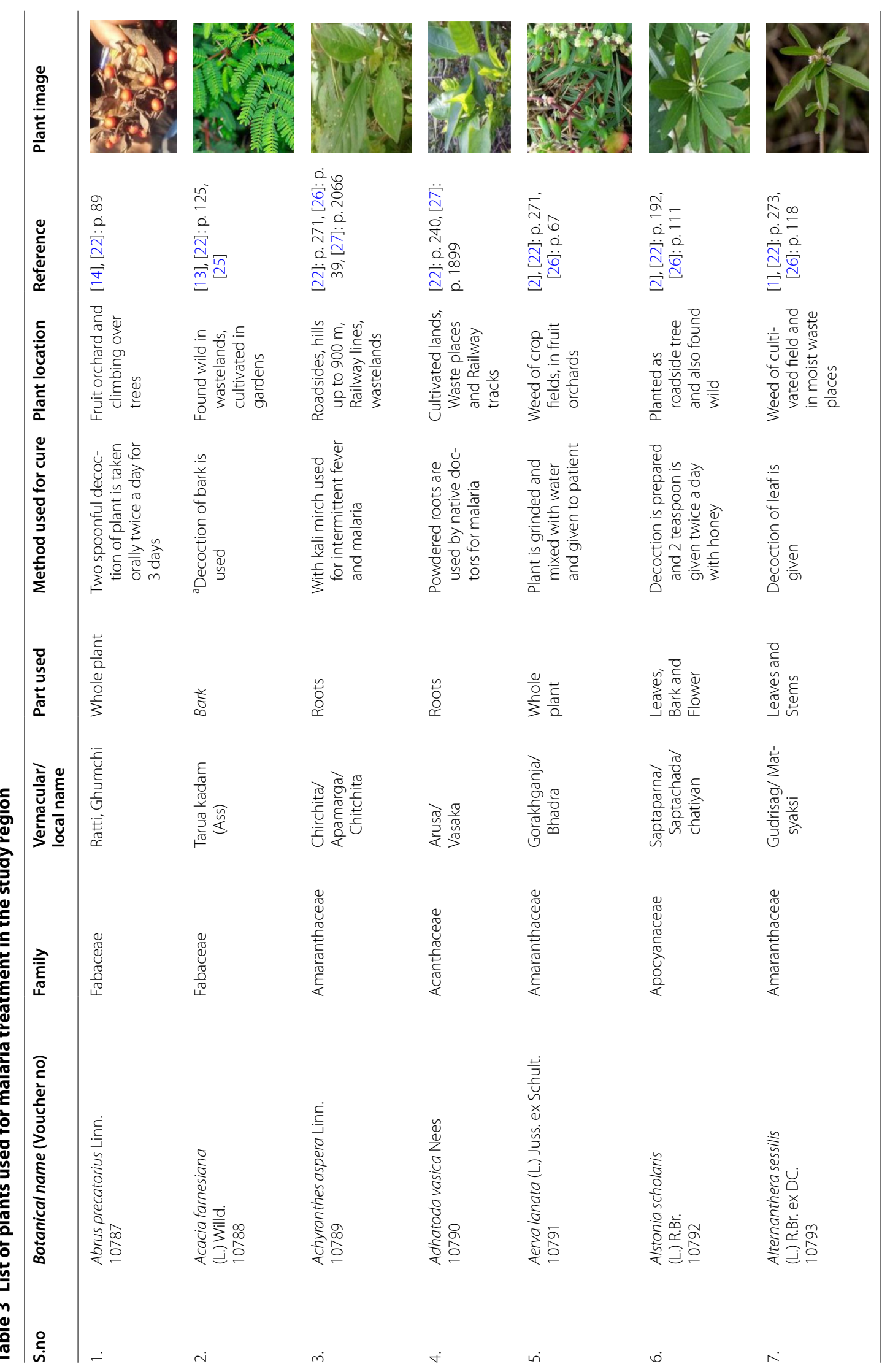




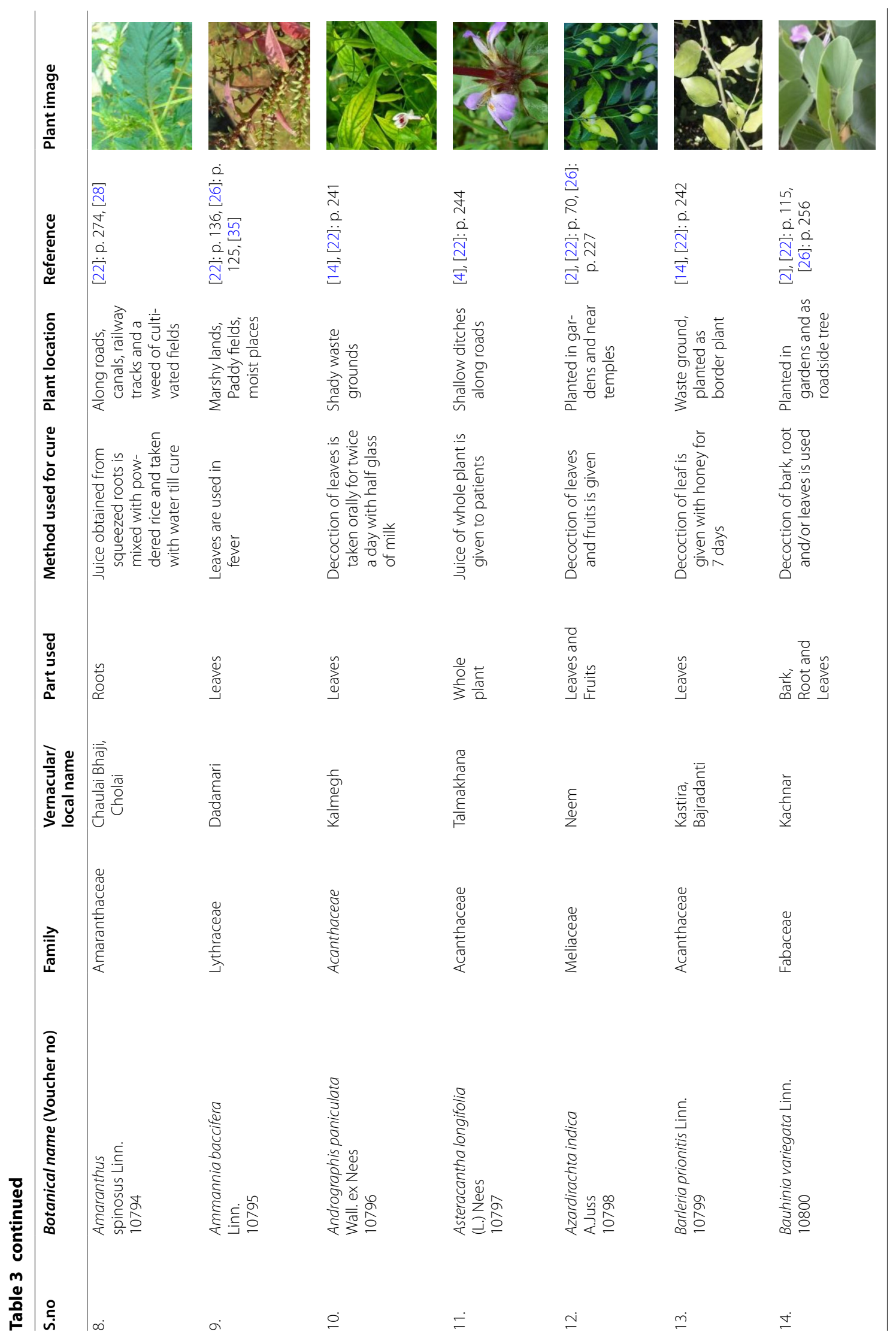




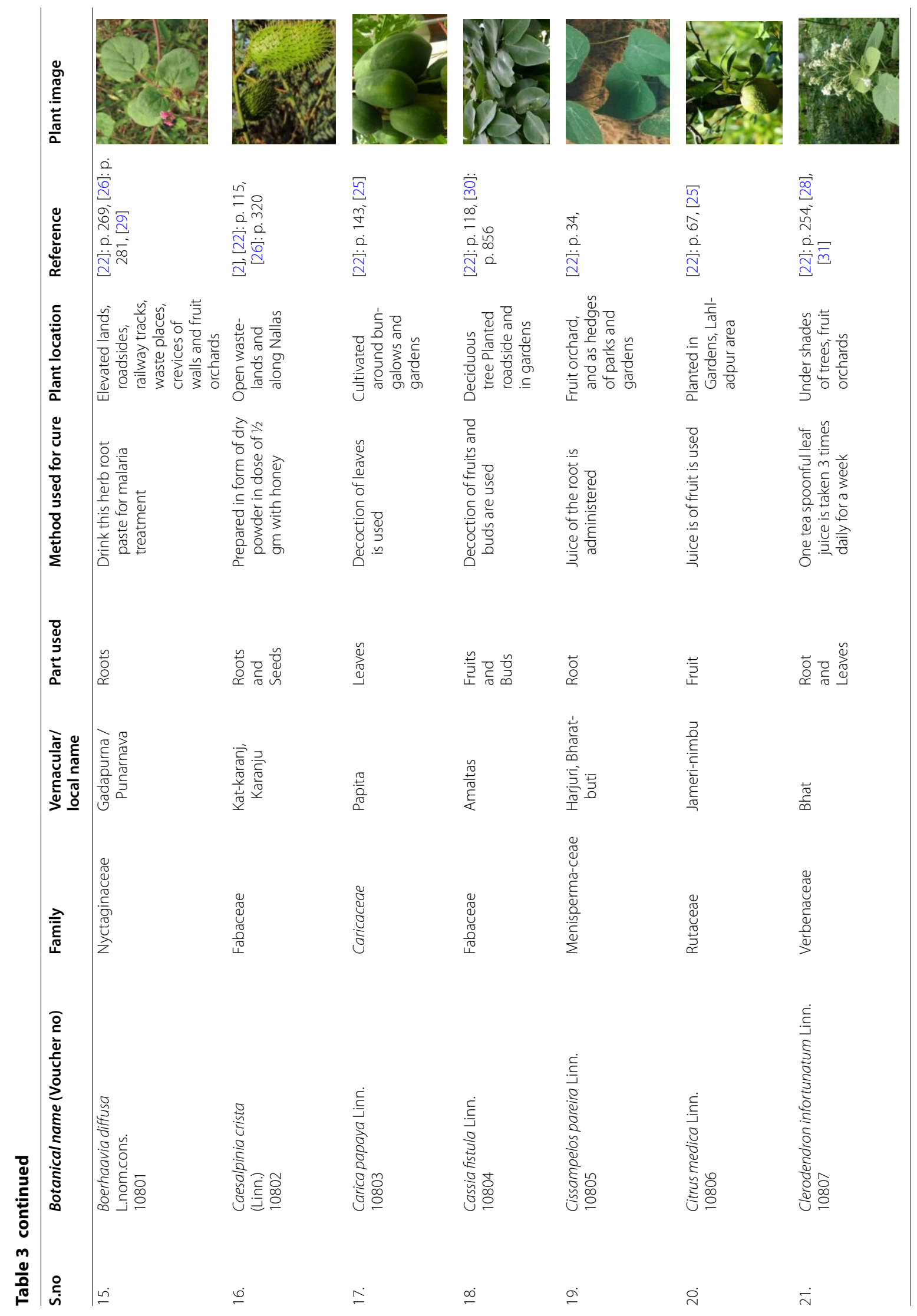




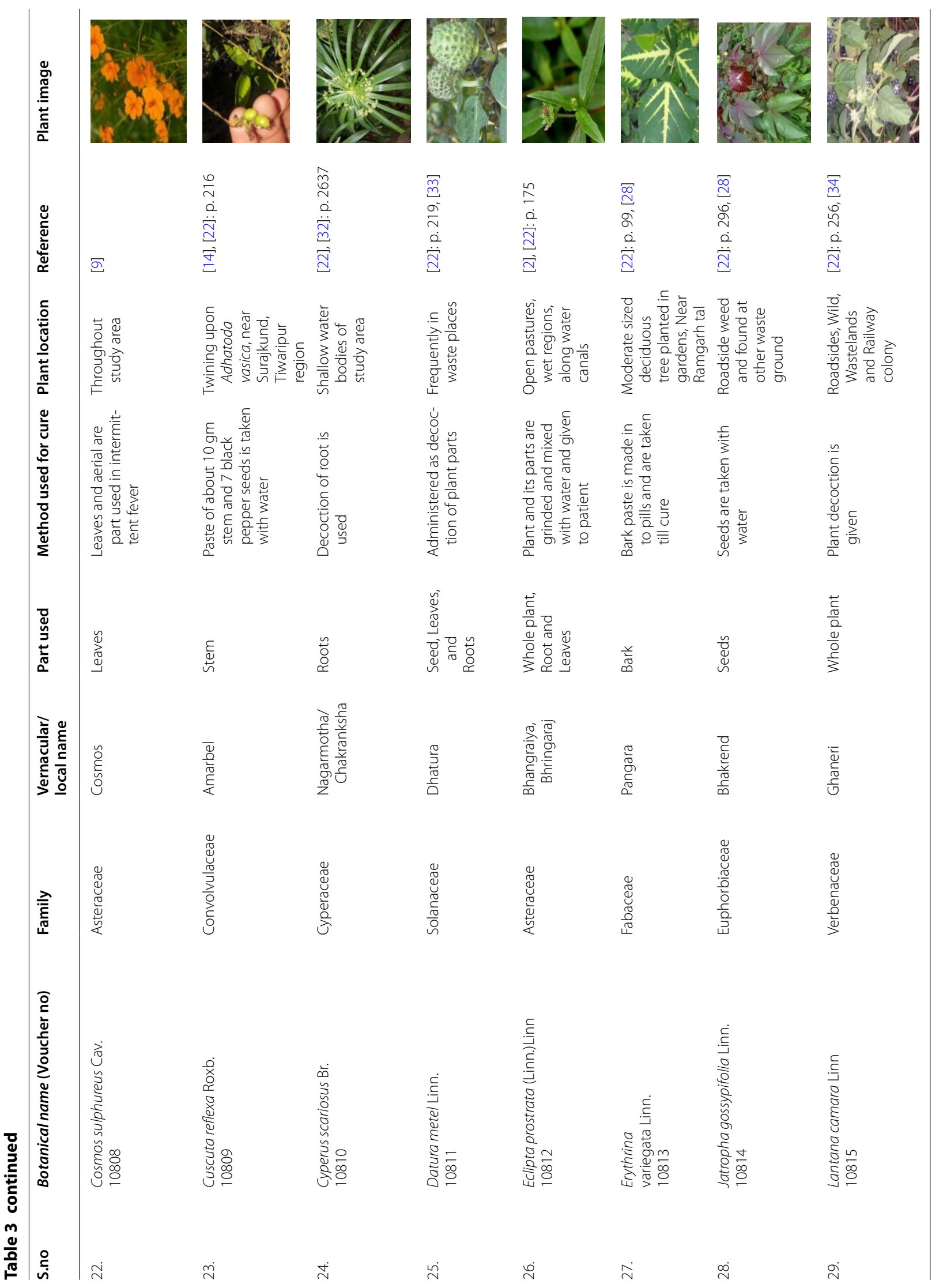




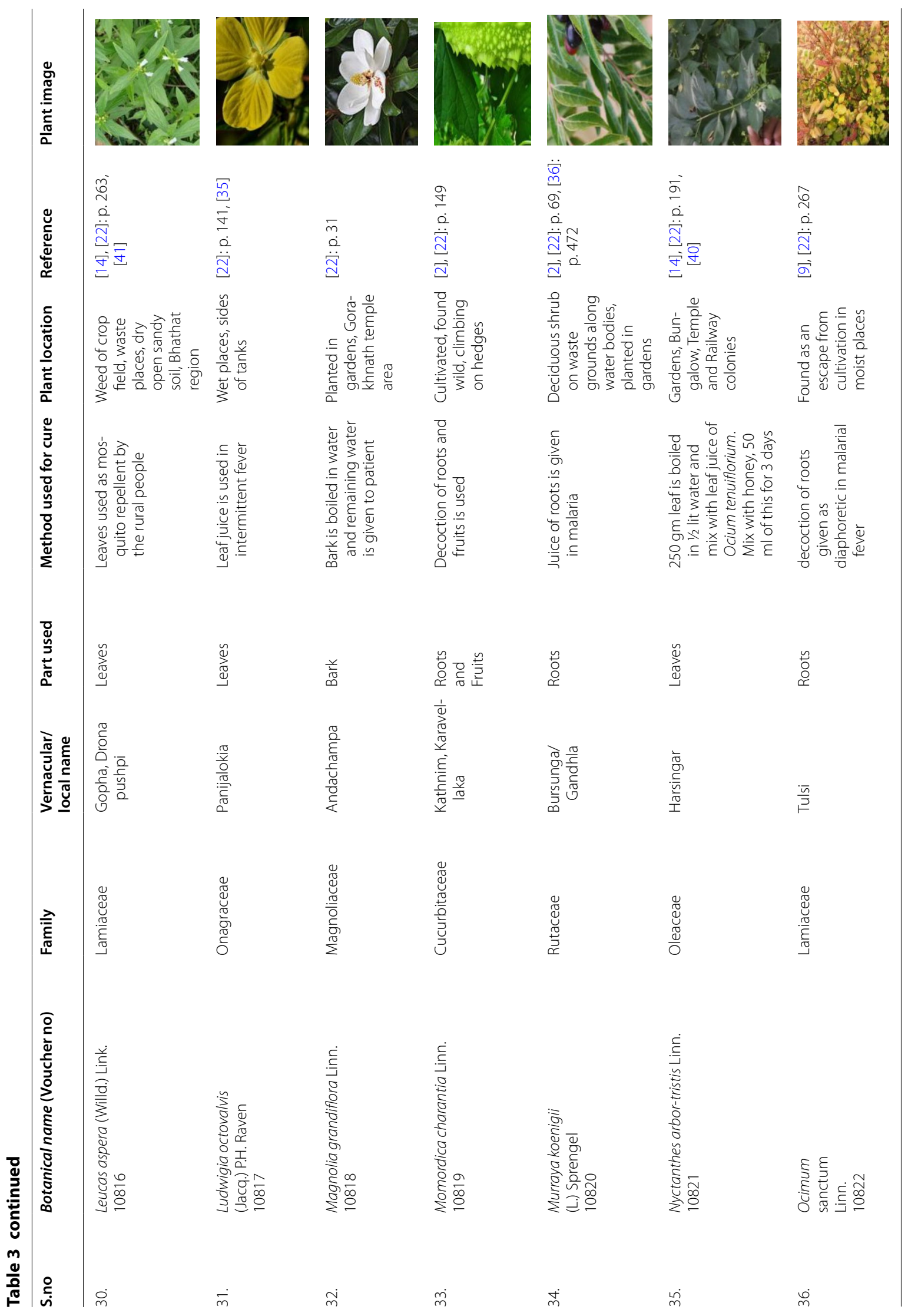




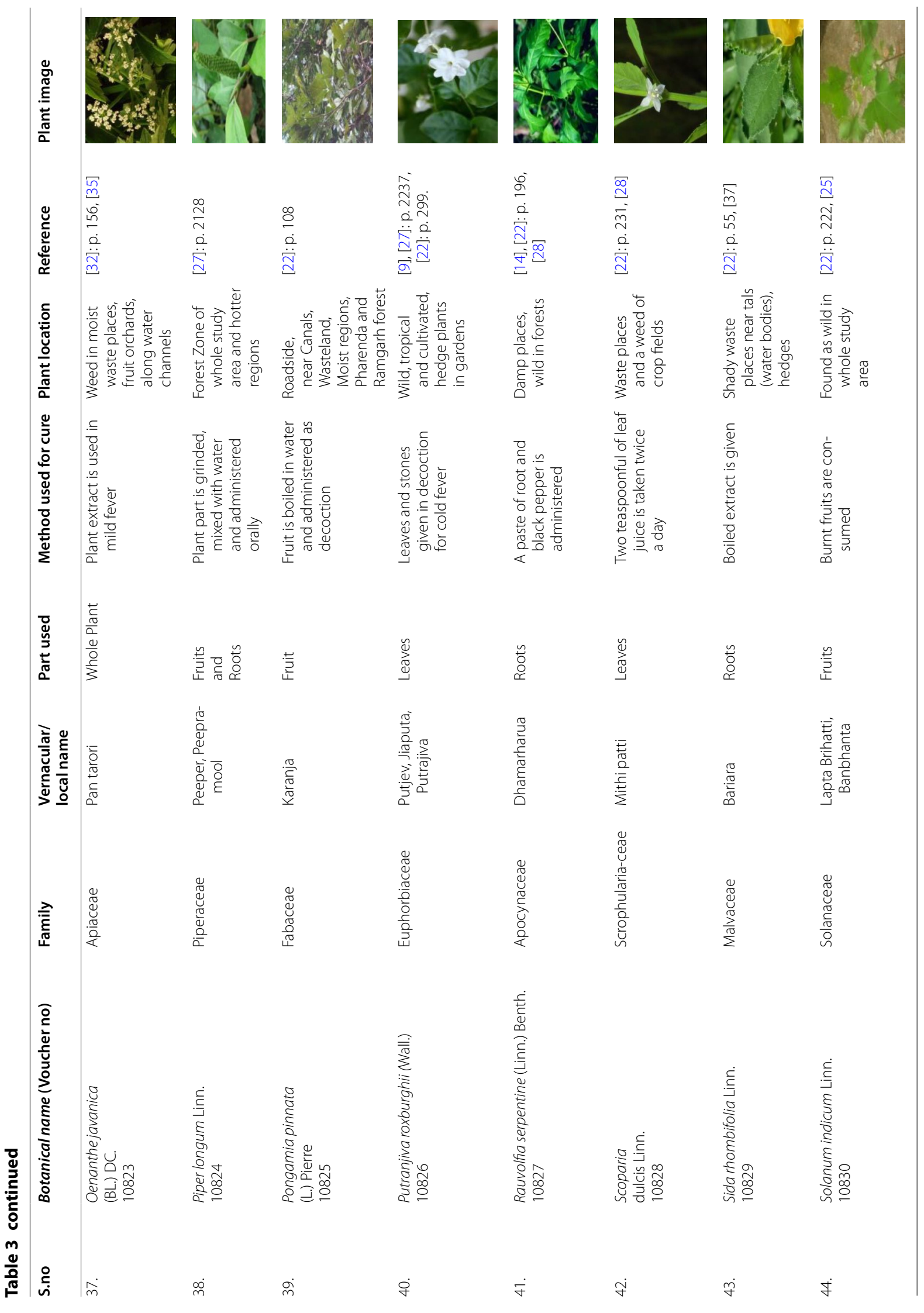




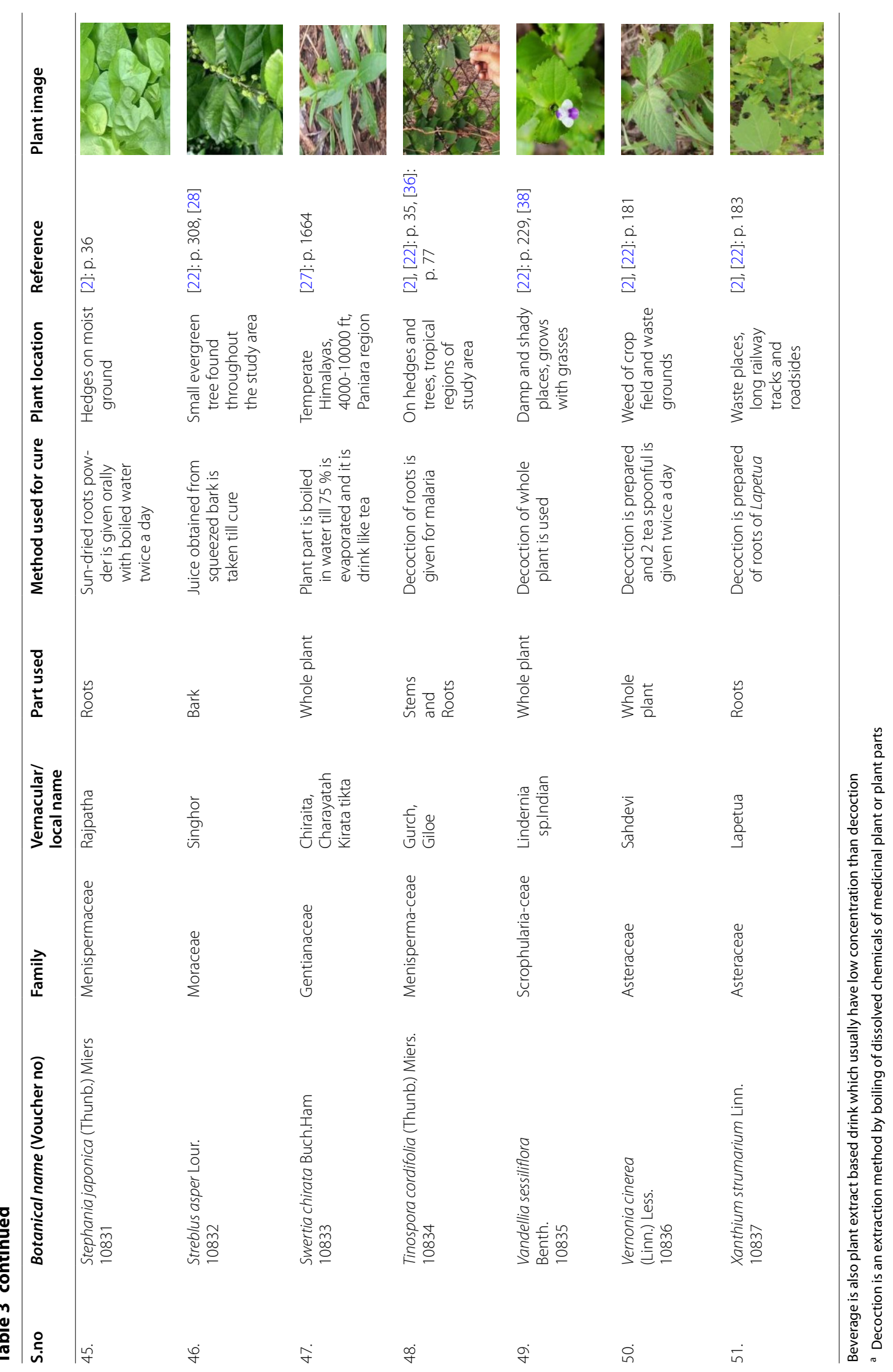




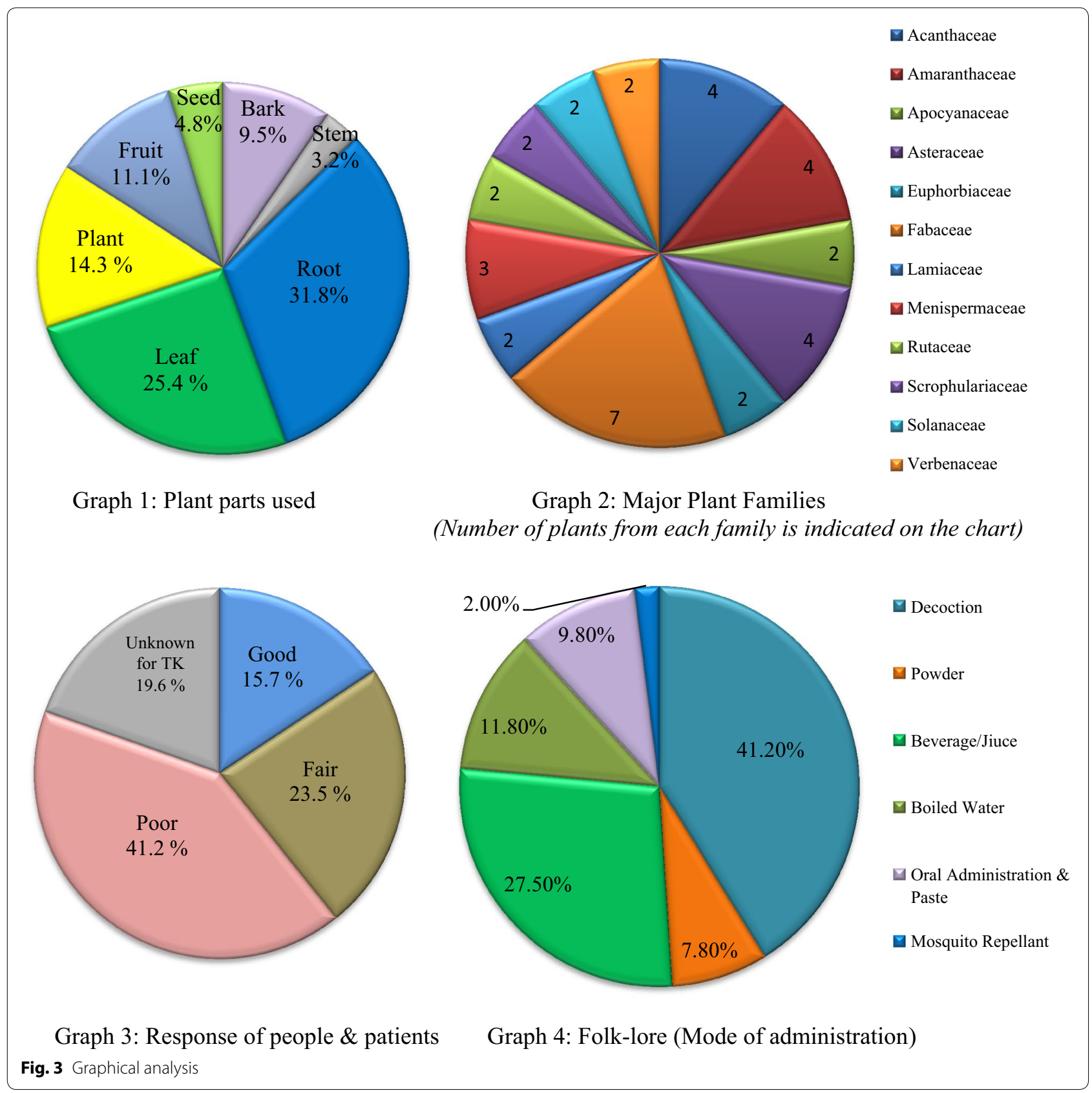

Plant identification and people's preferences:

- Considering people's perception there are 11 plants reported to be 'unknown' to the community people against malaria treatment while 8 plants are 'Good', 12 plants are 'Fair' and 21 plants are 'Poor' in their efficacy.

- Only 7 plants were reported during all three modes of interview conducted.

- Cassia fistula has got highest number of positive response $(\mathrm{n}=51)$ among community people, fol- lowed by Adhatoda vasica $(\mathrm{n}=49)$ and Swertia chirata $(\mathrm{n}=48)$. All these plants are most popular antimalarial plants.

Socio-economic and ethnographic results:

- $97.48 \%$ population is agrarian, mean age of respondents is 52.0 years, total literacy is $68.5 \%$, monthly income is 4298.3 INR ( 70.3 USD), and Gender (M/F) respondents were $(78 / 22) \%$. TK system usage is among $82 \%$ of population but they also rely on modern 
Table 4 Mathematical analysis of interviewee's response

\begin{tabular}{|c|c|c|c|c|c|c|}
\hline \multirow[t]{2}{*}{ Location } & \multirow{2}{*}{$\begin{array}{l}\text { Total } \\
\text { interviewees } \\
\text { (M/F) }\end{array}$} & \multicolumn{2}{|l|}{ Occupation } & \multirow[t]{2}{*}{ Literacy $^{\mathrm{a}}(\mathrm{M} / \mathrm{F})$} & \multirow{2}{*}{$\begin{array}{l}\text { Mean age } \\
\text { (years) }\end{array}$} & \multirow{2}{*}{$\begin{array}{l}\text { Monthly } \\
\text { income } \\
\text { (INR) }^{\mathrm{e}, \mathrm{d}}\end{array}$} \\
\hline & & Agri & Non-agri & & & \\
\hline Gorakhpur & $22(18 / 4)$ & $74 \%$ & $26 \%$ & $74.5(79 / 54) \%$ & 52.7 & 4915.0 \\
\hline Kushinagar & $38(27 / 11)$ & $78 \%$ & $22 \%$ & $63.7(68 / 53) \%$ & 55.0 & 3887.0 \\
\hline Maharajganj & $35(28 / 7)$ & $82 \%$ & $18 \%$ & $67.2(72 / 48) \%$ & 48.4 & 4093.0 \\
\hline Total $^{f}$ & $85(63 / 22)$ & $78 \%$ & $22 \%$ & $68.5(73 / 52) \%$ & 52.0 & 4298.3 \\
\hline \multicolumn{7}{|l|}{ Details of plants } \\
\hline Surveyed plants & 51 & & & & & \\
\hline Most commonly used plants & 3 & & & & & \\
\hline $\begin{array}{l}\text { Number of families of } \\
\text { surveyed plants }\end{array}$ & 27 & & & & & \\
\hline $\begin{array}{l}\text { Number of families with } \\
\text { two or more plants }\end{array}$ & 12 & & & & & \\
\hline \multicolumn{7}{|l|}{ Major plant families } \\
\hline Fabaceae & 7 & & & & & \\
\hline Asteraceae & 4 & & & & & \\
\hline Acanthaceae & 4 & & & & & \\
\hline Amaranthaceae & 4 & & & & & \\
\hline Menispermaceae & 3 & & & & & \\
\hline \multicolumn{7}{|c|}{ Most popular plants (With PK $\geq 55 \%$ ) } \\
\hline \multicolumn{7}{|c|}{ Adhatoda vasica Nees } \\
\hline \multicolumn{7}{|l|}{ Cassia fistula Linn. } \\
\hline \multicolumn{7}{|l|}{ Swertia chirata Buch.Ham } \\
\hline \multicolumn{7}{|l|}{ Geographical profile ${ }^{g}$} \\
\hline \multicolumn{2}{|l|}{ Average annual rainfall } & $1148.3 \mathrm{~mm}$ & & & & \\
\hline \multicolumn{2}{|l|}{ Average relative humidity } & $68.33 \%$ & & & & \\
\hline \multicolumn{2}{|l|}{ Average high temperature } & $30.92^{\circ} \mathrm{C}$ & & & & \\
\hline \multicolumn{2}{|l|}{ Average low temperature } & $19.58^{\circ} \mathrm{C}$ & & & & \\
\hline \multicolumn{2}{|c|}{ Average Mean Temperature } & $25.25^{\circ} \mathrm{C}$ & & & & \\
\hline \multicolumn{2}{|c|}{ Average no of days with precipitation } & 44.88 & & & & \\
\hline \multirow{2}{*}{\multicolumn{2}{|c|}{ Frequency of usage of traditional knowledge }} & Yes (\%) & No (\%) & & & \\
\hline & & $70(82 \%)$ & $15(18 \%)$ & & & \\
\hline
\end{tabular}

a Calculated on weighted mean \%, $M$ males, $F$ females

b Mean of ages of $M$ and $F$

c Based on India census 2011

d Economics and Statistics Division, Govt. of Uttar Pradesh, India

e 1 USD 61.11 INR

f Calculated on arithmetic mean \%

$g$ Based on satellite imagery and Climate Research Unit (CRU) UK

method of allopathic treatment when TKS becomes ineffective.

\section{Discussion}

In the study area two species namely Nagarmotha (Cyperus scariosus) and Goma or Drona pushpi (Leucas aspera) are at the verge of extinction mainly due to the change in water reservoir structure i.e. because of loss of water bodies like ponds and other reservoirs for the former and because of change in land-use pattern for the latter. The ethnoecology of the study region does not produce the scintillating picture. Further, due to ruthless exploitation, many important medicinal plants species are becoming rare and some of them are critically endangered as per the IUCN (International Union for Conservation of Nature and Natural resource), Switzerland red list criteria. It is estimated that $10 \%$ of all plant species are currently endangered in India [39]. 
Table 5 IUCN status for frequently used plants towards malaria cure

\begin{tabular}{llllll}
\hline S. no & Plant species & IUCN status & S. no & Plant species & IUCN status \\
\hline 1 & Abrus precatorius & Not threatened & 11 & Cassia fistula Linn & Not yet been assessed \\
2 & Achyranthes aspera & Not yet assessed & 12 & Cuscuta reflexa Roxb & Not yet been assessed \\
3 & Adhatoda vasica & Not yet assessed & 13 & Cyperus scariosus & Not yet been assessed \\
4 & Alstonia scholaris & Least concerned & 14 & Leucas aspera & Not yet been assessed \\
5 & Andrographis paniculata & Not yet assessed & 15 & Ocimum sanctum & Not yet been assessed \\
6 & Azardirachta indica & Not yet assessed & 16 & Piperlongum & Not yet been assessed \\
7 & Bauhinia variegata & Not yet assessed & 17 & Pongamia pinnata & Least concerned \\
8 & Boerhaavia diffusa & Not yet assessed & 18 & Putranjiva roxburghii & Not yet been assessed \\
9 & Caesalpinia crista & Not Threatened & 19 & Swertia chirata & Not yet been assessed \\
10 & Carica papaya & Not yet assessed & 20 & Tinospora cordifolia & Not yet been assessed \\
\hline
\end{tabular}

Based on IUCN red list criteria

It is found that 51 plant species out of various plants studied in the region belong to 27 families are used by native people malaria treatment (Table 3 ) and out of these families studied certain family of plants like, Fabaceae (7), Acanthaceae (4), Amaranthaceae (4), Asteraceae (4), and Menispermaceae (3) are prevalent in the region. A commendable work has been done by Duthie for the flora of Flora of Upper Gangetic Plains [21] and by Srivastava for the Flora Gorakhpurensis [22]. Some plants like Cosmos sulphurous, Piper longum and Swertia chirata were found in the study area which missed its place in the Srivasatava's work and also these are not listed in Duthie's work. These plants might have grown up in the area during the recent decades or may have come through migrations.

Spatial distribution of antimalarial plants found in the study area including types of habitat is supplied in Table 3. Plant diaspora usually found in the tree/forest, open pastures, river and water body regions; while some are found in some specific locations like Lahladpur, Surajkund, Tiwaripur, Ramgarh Tal, Gorakhnath Temple, Pharenda (forest), Ramgarh (forest), Paniara, Bhathat areas whereas and some are found vaguely throughout the region. Further, there are few plants which are found in fruit orchards, waste/open areas and along railway tracks. Some are distributed in moist waste places, crop fields and along roadside and some are in marshy lands, moist places, garden and temples (in settlements) and near nallas/canals.

The region falls in low socio economic zones with monthly income $\sim 70.3$ USD while population is agrarian (97.48\%) and hence their obvious dependency for malaria cure is TKS. It is also found that malaria incidences are relatively higher in the socio-economic inferior regions. There are sizeable amount of Vaidya/ Hakims (Experts in TKS based applications) who derive their raw material from nearby forests, railway tracks, fruit orchards or from target plantations. The region has
$1,436,878$ as total households in which $87.98 \%$ is rural while merely $12.02 \%$ is urban and demographic divide lies with $51.25 \%$ males while $48.75 \%$ females in the entire study area [20].

In drawing Pie Chart for plant parts used; rationale used is total number of plants with a particular plant part used is divided by total plants in the study area and multiplied by 100 to compute its \%. It is found that among collected plants mostly $(31.75 \%)$ roots are used for malaria treatment followed by leaf $(25.40 \%)$ and the least used part of plant is stem $(3.17 \%)$ preceded by seeds $(4.76 \%)$ (Graph 1). Details of most widely plant parts used is necessary to ascertain the significance of that particular part and to establish the coherence of the work with other similar works e.g. for the medicinal plants of BHU region of Varanasi UP [2]. It has been established that for that given region $30 \%$ of preparations are derived from roots which is maximum in plant parts used. In another similar work of Shankar et al. [13] on antimalarial plants of northeast India, frequently used plant parts were roots (31\%), after leaves (33\%). It can be established that in most of the cases root is most frequently used towards medicinal purposes and in some cases leaves are also widely used. Thus, there is a need of expertise for extraction of artemisinin or quinine alkaloid compounds preferably from the roots and leaves.

There are 12 plant families including Acanthaceae, Amaranthaceae, Apocyanaceae, Asteraceae, Euphorbiaceae, Fabaceae, Lamiaceae, Menispermaceae, Rutaceae, Scrophulariaceae, Solanaceae and Verbenaceae that have more than one plant in the region (Graph 2) while Fabaceae makes highest contribution of 7 plants namely Abrus precatorius, Acacia farnesiana, Bauhinia variegate, Caesalpinia crista, Cassia fistula, Erythrina variegate and Pongamia pinnata (Table 3). Response of these plants among people and patients was upright and it had been acting as good alternative to modern means 
of medication and had been catering to the need of millions from the ancient times. Folklore (mode of administration) of plant parts is decoction (41.2 \%) where plant parts are boiled in water and water is evaporated to extend that plant part makes thick syrupy liquid. It is an excellent way to prepare herb with an awful taste. Decoctions of roots and barks are very often prepared while decoctions of leaves, flowers, or seeds are rarely prepared.

The interview was trifurcated in three categories of field, Vaidya/Hakims and house to house to understand the method of plant identification and people perception (Table 2). It was found that as many as seven plants were obtained through all three interview modes. Three indices PK, PR and PI are used to understand perception of plants among community people. Total number of positive responses (n) were collected and combined for all 51 reported plants. PK signifies popularity of a plant as antimalarial. If $\mathrm{PK}>55 \%$; such plants are considered as most popular plants. For 11 plants, $\mathrm{PK}=0$ was reported that signifies plant is unknown in the locality among people, during field survey they were found and such plants also found space in literature and journals. Plants with $\mathrm{PK}=0$ are highly important and further work has to be done to enhance its PI which will lead to increased plant's medicinal utility. These are the plants which have least importance among communities and these are ecologically available for future potential application. These plants are not known due to over-dependence on plants with $\mathrm{PK}>55$, in the study area.

PR has been assigned to each plant either as 1, 2 or 3 depending on people perception as well as research findings. 1 signifies for highly effective in treatment while 3 for least effective in treatment. There are 19 plants with PR as 1 i.e. They are rated as effective in malaria treatment. It is observed that indices like PR and PI are in resonance for most of the plants; higher is $\mathrm{PR}(\mathrm{PR}=1)$ higher is PI (Good) and vice versa and runs parallel. 21 plants have 'Poor' PI (41.2 \%). It is because of its inefficacy towards fever, intermittent fever or malaria cure and hence these plants are least preferred by the local communities. IUCN status of plants with 'fair' and 'good' impression (PK > $30 \%$ ) towards malaria cure is tabulated to understand geographical health of the plant as per the red list criteria (Table 5).

Having life in close vicinity of the nature, traditional societies have acquired unique knowledge about the use of flora and fauna in wild, most of which are still unknown to the common masses. The research findings can be used by both scientific community and common rural/tribal people for bio-prospecting of these natural resources sustainably. The former can extract the tables obtained in the research work to obtain a suitable plant for finding a lead molecule towards a drug discovery project; while the latter can use Table 3 information to meet the local demand for malaria cure. Plant image, methodology and plant location can be seen together to bring malaria cure measures in friendly manner for local communities at their door step. This will be much useful for the developing countries like India where the modern medical facilities have still not penetrated down deeper. It provides sustainable alternate to the existing system of malaria medication. Findings of such works should be made open and unrestricted for its elaborated application to benefit the public at large. The work has also included many plants that are not widely used and are not popular in the study area. This widens the scope of extraction of other non-traditional plants in cases of poor ethnoecology especially during extinction or vulnerability of the traditional plants because of over harvesting and over exploitation of these medicinal plants.

\section{Conclusion}

The study region has monsoonal rainfall with numerous rivers emanating from Himalayas and low gradient leads to stagnation of water that makes it favourable for vector borne diseases. TK coupled with information technology makes the study highly useful for basic amenity stressed population. The lack of ecology-related knowledge and awareness which is evident from low socio-economic profile of the study region gives signs of over harvesting of plants. This is reinforced by the observed poor geographical health of plants as some plants are found vulnerable; some has become rare, while some are nearly extinct. It further widens the horizon of socio-economic based utility of this kind of research work. The research work fully addresses the issue of making public the availability of information of antimalarial plants for its cheapest and sustainable harvesting for malaria cure locally and it opens gates for numerous opportunities of public health at large.

The work carried out revealed the plants recorded are highly valuable for antimalarial application and in future, bio-prospecting projects can be further initiated for sustainable harvesting towards developing antimalarial drug for curing malaria at large. It would help researchers to find out suitable lead molecules with antimalarial activity towards drug discovery. The study provides ample ground to believe that the traditional medicinal system practice using native medicinal plants is alive and well functioning in the selected area. Many communities use antimalarial plant parts and whole plant for their primary healthcare. It is primarily due to lack of modern medicines, medications, self-reliance on herbs, poor economic condition and more importantly faiths in TK System. The treatment of malaria with plants and plant parts 
causes little or no side effects and also it is very cheap and affordable. Some plants are nearly extinct in the region, the reason being change in land use pattern and shrinking of water bodies along with over harvesting of herbs. The bio-depletion of these antimalarial plants is due to the burgeoning population and unscientific management of the natural resources.

The work has highlighted the fact that some species with medicinal applications are not ethnoecologically rich. People residing in the study area are not aware that some of the medicinal plants are becoming extinct gradually. The current work of listing these antimalarial plants would assist people in identifying ecologically sensitive species and hence adoption of regeneration technique for that particular plant species, thus it supports health and economy of the community. There exists alarming need to conserve and protect these important species for sustainable harvesting. A serious endeavour has to be taken to save these natural resources for the generations to come. Study area in the work happens to be least developed part of one of the poorest State in India. Thus, working for low socio-economic profile region will certainly be useful at larger scale and will bear extended benefits when the work will be thoroughly evaluated.

\section{Future work}

Exhaustive research should be done on comparative analysis of different antimalarial plants to comprehend if the local evaluation of the effectiveness of the different species can be scientifically authenticated. Listed medicinal plants can be potentially used for extracting antimalarial plants content for further chemical extraction and its analysis as a potential constituent of malaria drug can be established. The plants can be further studied across its family to establish antimalarial activity relationship of various families and correlation based study can also be done to generate coefficient of correlation for a particular plant family as an antimalarial. The present findings can be extended to chalk out a complete roadmap of geographical health of antimalarial plants in terms of IUCN criteria of red list and for detailed ethnoecology work.

\section{Additional file}

Additional file 1. Survey format.

\section{Authors' contributions}

$\mathrm{AQ}$ proposed the idea, made analysis, drafted the manuscript and implemented the idea. AML channelized the work, made critical evaluation and provided continuous feedbacks. RA was responsible for socio-economic evaluation and ethnoecology and was responsible for carrying theoretical work related to the manuscript preparation. All authors read and approved the manuscript and designed the overall architecture of the work. All authors read and approved the final manuscript.
}

\section{Author details}

1 Center for Biology and Bioinformatics, School of Computational and Integrative Sciences, Jawaharlal Nehru University, New Delhi 110067, India. ${ }^{2}$ Centre for the Study of Regional Development, Jawaharlal Nehru University, New Delhi, India. ${ }^{3}$ Indira Gandhi National Forest Academy, Dehradun, India.

\section{Acknowledgements}

The authors express our deepest regards to Vaidyas/Hakims, herbalists, traditional healers and various rural people, who provided lot of information on TK system of the study area. We also acknowledge the computer laboratory facility at SCIS and CSRD, Jawaharlal Nehru University, New Delhi for the essential support in carrying out this work. We are highly indebted to the CSIR for providing financial assistance rendered which kept constant motivation throughout the work. The author is also grateful to Dr. HB Naithani and Dr. Vinay Kant Misra, IFS for plant verification and cross validating the authority of botanical names and is equally indebted to the Ministry of Environment and Forest, MoEF Govt. of India for its continuous support towards making this work plausible. Further, author is grateful to IGNFA, Dehradun for its constant motivation and encouragements.

\section{Competing interests}

The authors declare that they have no competing interests.

Received: 19 September 2014 Accepted: 21 December 2015 Published online: 04 February 2016

\section{References}

1. Qayum A, Lynn A, Arya R. Traditional knowledge system based GIS mapping of antimalarial plants: spatial distribution analysis. J Geogr Inf Syst. 2014. doi:10.4236/jgis.2014.65041.

2. Verma AK, Kumar M, Bussmann RW. Medicinal plants in an urban environment: the medicinal flora of Banares Hindu University, Varanasi, Uttar Pradesh. J Ethnobiol Ethnomed. 2007;3:35.

3. National Vector Borne Disease Control Programme: Malaria situation in India. Ministry of Health and Family Welfare, Delhi. Govt. of India. http:// www.nvbdcp.gov.in/Doc/malaria1.pdf.

4. Qayum A, Lynn AM, Arya R, Jaiswal SK. GIS integrated epidemiological indices for risk area identification towards malaria control measures. IJEAT. 2013;2(6):376-81.

5. National Vector Borne Disease Control Programme: Guidelines for diagnosis and treatment of malaria in India 2009.

6. Qayum A, Arya R, Kumar P, Lynn AM. Socio-economic, epidemiological and geographic features based GIS-integrated mapping to identify malarial hotspot. Malaria J. 2015;14:192. doi:10.1186/s12936-015-0685-4.

7. Gupta A, Singh AK, Qayum A. Evaluating ancient Indian history and culture towards malaria control measures based on traditional knowledge system. Int J Interdiscip Multidiscip Stud. 2014;1(8):181-90.

8. Pandey AK, Tripathi NN. Aromatic plants of Gorakhpur division: their anti-mycotic properties and medicinal value. Int J Pharm Sci Rev Res. 2011;7(2):142-7.

9. Pandey AK, Tripathi NN. Diversity and distribution of aromatic plants in forests of Gorakhpur division, U.P., India. Biol Forum Int J. 2010;2(2):25-33.

10. Kumar V, Akhtar M. Ethanomedicinal solanaceous plants of eastern Uttar Pradesh. Ind J Life Sci. 2013;2(2):95-8.

11. Tomar A. Folk medicinal uses of plant roots from Meerut district, Uttar Pradesh. Ind J Tradit Knowl. 2009;8(2):298-301.

12. Srivastava R. Underutilised fruits: a potential of local food resource. Int J Pharm Bio Sci. 2013;4(3):1301-5.

13. Shankar R, Deb S, Sharma BK. Antimalarial plants of northeast India: an overview. J Ayurveda Integr Med. 2011;3(1):10-6.

14. Pandal SK, Rout SD, Mishra N, Panda T. Phytotherapy and traditional knowledge of tribal communities of Mayurbhanj Orissa India. J Pharmacognosy Phytother. 2011;3(7):101-13.

15. Bahekar S, Kale R. Herbal plants used for the treatment of malaria-a literature review. J Pharmacognosy Phytochem. 2013;1(6):141-6.

16. Kumar KS, Bhowmik D, Chandira M. Swertia chirayita: a traditional herb and its medicinal uses. J Chem Pharm Res. 2010;2(1):262-6. 
17. Kamaraj C, Kaushik NK, Rahuman AA, Mohanakrishnan D, Bagavan A, Elango $\mathrm{G}$, et al. Antimalarial activities of medicinal plants traditionally used in the villages of Dharmapuri regions of South India. J Ethnopharmacol. 2012;141:796-802.

18. Prakash A. Uses of some threatened and potential ethnomedicinal plants among the tribals of Uttar Pradesh and Uttrakhand in India. In: National Conference on Forest Biodiversity_Earth's Living Treasure. 2011:93-99.

19. Pushpangadan P, Kumar B. Ethnobotany, CBD, WTO and the Biodiversity Act of India. Ethnobotany. 2005;17:2-12.

20. Directorate of Census Operations UP: Census of India 2011. Uttar Pradesh administrative atlas. 2012.

21. Duthie JF. Flora of upper gangetic plains, vol I and II. Botanical Survey of India.1960.

22. Srivastava TN. Flora Gorakhpurensis. New Delhi: Today and tomorrow's print and Publ; 1976.

23. Zulfeqar AM. Herbal Medicine. New Delhi:APH Publications;2008. p. 31-56.

24. Asase A, Oteng-Yeboah AA, Odamtten GT, Simmonds MS. Ethnobotanical study of some Ghanaian anti-malarial plants. J Ethnopharmacol. 2005;99:273-9.

25. Sharma UK. Medicinal plant of Assam. Dehradun: Bishen Shingh Mahendra Pal Singh Publisher; 2004.

26. Vaidyaratnam PS Varier's, Arya Vaidya Sala: Indian medicinal plants. Vol I, Orient Longman, 1994.

27. Kitikar KR, Basu BD: Indian Medicinal Plants, vol III. Periodical experts Delhi;1975.

28. Rahmatullah M, Hossan S, Khatun A, Seraj A, Jahan R. Medicinal plants used by various tribes of Bangladesh for treatment of malaria. Hindawi Publishing Corporation, Malaria Research and Treatment;2012.

29. Bhowmik D, Sampath KKP, Srivastava S, Paswan S, Sankar A. Traditional Indian herbs Punarnava and its medicinal importance. J Pharmacognosy Phytochem. 2012;1(1):52-8.

30. Kitikar KR, Basu BD. Indian medicinal plants, vol II.. Periodical Experts Delhi;1975.
31. Kohli YP, Mibang T, Chaudhuri SK. Ethnomedicines of the tribes of Arunachal Pradesh. Itanagar: Himalayan publishers; 2003.

32. Kitikar KR, Basu BD. Indian Medicinal Plants, vol IV. Periodical Experts Delhi; 1975

33. Mahanti N. Tribal ethno-botany of Mizoram, tribal studies of India. New Delhi: Inter India Publications; 1994.

34. Mishra SB, Dwivedi S, Shashi A, Prajapati K. Ethnomedicinal uses of some plant species by ethnic and rural peoples of the Salem district of Tamilnadu with special reference to the conservation of vanishing species. Ethnobot Leaflets. 2008;12:873-87.

35. Gond DK, Kumar S, Samuel CO, Saini DC, Kulshreshtha K, Abbasi P. Ethano-Medicinal Plants on Indigenous Wetland Plants of Mau District of Uttar Pradesh. Uttar Pradesh: Biodiversity and Conservation India, National conference on climate change; 2012. p. 33-8.

36. Kitikar KR, Basu BD. Indian medicinal plants, vol I. Periodical Experts Delhi;1975.

37. Purkayastha P, Dutta M, Nath SC. Ethno-medicinal plants from DibruSaikhowa biosphere reserve Assam. Ind J Trad Knowl. 2007;6:477-80.

38. Shankar R, Rawat MS. Medicinal plants vis a vis forest management in Arunachal Pradesh: ayurveda and drugs for all. New Delhi : Himalayan Publisher; 2007. p. 110-8.

39. Pandey AK, Patra AK, Shukla PH. Medicinal plants in Satpura Plateau of Madhya Pradesh: current status and future prospects. Ind Forester. 2005;131(7):857-83.

40. Puri A, Saxena R, Saxena RP, Saxena KC, Srivastava V, Tandon JS. Immuno stimulant activity of Nyctanthes arbor-tristis L. J Ethnopharmacol. 1994;42(1):31-7

41. Maheswaran R, Sathish S, Ignacimuthu S. Larvicidal activity of Leucas Aspera (Willd.) against larvae of Culex quinquefasciatus Say. and Aedes aegypti L. Int J Integr Biol. 2008;2(3):214-7.

\section{Submit your next manuscript to BioMed Central and we will help you at every step:}

- We accept pre-submission inquiries

- Our selector tool helps you to find the most relevant journal

- We provide round the clock customer support

- Convenient online submission

- Thorough peer review

- Inclusion in PubMed and all major indexing services

- Maximum visibility for your research

Submit your manuscript at www.biomedcentral.com/submit 